\title{
Survival rate and prognostic factors in advanced cervical cancer patients accompanied by renal impairment
}

\author{
Imam Rasjidi ${ }^{\nabla}$, Laila Nuranna ${ }^{*}$, M. Farid Aziz ${ }^{*}$, Andrijono ${ }^{*}$, Sigit Purbadi ${ }^{*}$, Rochani $^{\infty}$, Nana Supriana ${ }^{\S}$, \\ Dharmeizar ${ }^{f}$, Bambang Sutrisna ${ }^{\#}$
}

\begin{abstract}
Abstrak
Tujuan penelitian ini adalah untuk memperoleh informasi tentang survival kanker servik stadium lanjut dengan gangguan fungsi ginjal (KSSLGFG) serta faktor-faktor yang mempengaruhinya. disamping itu diharapkan dapat ditemukan sistem scoring untuk prediksi kematian pasien KSSLGFG. Rancangan studi yang digunakan adalah retrospektif kohort. Data yang dikumpulkan berasal dari rekam medik penderita KSSLGFG dari 1 januari 1998 sampai 31 Desember 2003 di Rumah Sakit Umum Pusat Nasional Dr Cipto Mangunkusumo, Jakarta, dengan jumlah sampel 70 kasus. Hasil penelitian menunjukkan rerata Survival secara keseluruhan pasien KSSLGFG 8,2 bulan, survival bulan ke-6 sebesar 39\%, survival 1 tahun sebesar 3,2\%. Median survival 5,3 bulan. Faktor-faktor yang berpengaruh terhadap survival pasien KSSLGFG adalah gambaran histopatologik (sel adenoskuamosa dan diferensiasi sel), ketebalan korteks ginjal < $1 \mathrm{~cm}$ dan nefrostomi. (Med J Indones 2005; 14: 173-8)
\end{abstract}

\begin{abstract}
The objective of this study was to obtain information on the survival rate of advanced cervical cancer patients with renal impairment (ACCRI) and its prognostic factors. In addition, it is hoped that by this method the scoring system for predicting the death of ACCRI patients hopetully could be obtained. Design of the study used was retrospective cohort study. Data collected were retrieved from medical records of ACCRI patients from 1 January 1998 to 31 December 2003 at Dr. Cipto Mangunkusumo National Central General Hospital, Jakarta, with a total sample of 70 cases. The results of the study showed that mean survival of all ACCRI patients was 8.2 months, mean survival at sixth month was 39\%, and mean survival at one year was 3.2\%. Median survival was 5.3 months. Prognostic factors affecting the survival of ACCRI patients included histopathological type (adenosquamous cell and cell differentiation), cortical thickness of the kidney less than $1 \mathrm{~cm}$, and nephrostomy. (Med J Indones 2005; 14: 173-8)
\end{abstract}

Keywords: Advanced cervical cancer, renal impairment, nephrostomy, survival, prognostic factor, scoring system

$\nabla$ Fellow of Gynecology oncologic Consultant, Department of Obstetric and Gynecology, Faculty of Medicine, University of Indonesia/Dr Cipto Mangunkusumo Hospital, Jakarta, Indonesia

* Division of Oncology, Department of Obstetrics and Gynecology, Faculty of Medicine University of Indonesial Dr. Cipto Mangunkusumo General Hospital, Jakarta, Indonesia

¿ Department of Urology, Faculty of Medicine, University of Indonesia/Dr. Cipto Mangunkusumo Hospital, Jakarta, Indonesia

$\S$ Department of Radiotherapy, Faculty of Medicine, University of Indonesia/Dr. Cipto Mangunkusumo Hospital, Jakarta, Indonesia

${ }^{f}$ Department of Internal Medicine, Faculty of Medicine, University of Indonesia/Dr. Cipto Mangunkusumo Hospital, Jakarta, Indonesia

\# Department of Epidemiology, Faculty of Public Health, University of Indonesia, Jakarta, Indonesia
A total of 250 cases of advanced cervical cancer (62\% of which were stage IIB to IVA) ${ }^{1}$ were treated at Dr. Cipto Mangunkusumo General Hospital.

The medical treatment performed on these patients was radiotherapy. However, most of the patients showed a low response.

A survey conducted in the United States in 1978 showed that the primary cause of death in patients with advanced cervical cancer was low response to radiotherapy or local failure (59\%). A study conducted at Dr. Cipto Mangunkusumo General Hospital 1994, on the other hand, revealed that 37 cases $(30 \%$ of advanced cervical cancer patients) suffered from renal failure as a result of ureteral obstruction. ${ }^{3}$ Most of the ureteral obstructions in cervical cancers were associated with mass pressure. 
This condition made it difficult to overcome the obstruction by cytoscopic retrograde from the bottom. Renal impairment that also followed made it difficult, or almost impossible, to perform radiotherapy. Nephrostomy may become an option to correct renal impairment, and with it the survival rate of ACCRI patients.

The aim of this study was to identify the survival rates and prognostic factors of advanced cervical cancer patients accompanied by renal impairment. The present study also attempted to obtain a scoring system for predicting mortality among ACCRI patients.

\section{METHODS}

The present study was a retrospective cohort trial, using data retrieved from medical records of Dr. Cipto Mangunkusumo General Hospital. All patients with advanced cervical cancer admitted to Dr. Cipto Mangunkusumo General Hospital from 1 January 1998 to 31 December 2003 were enrolled. The inclusion criteria were: 1) Cervical cancer stage IIIB, IVA, IVB according to FIGO classification ${ }^{4}$; 2) Recurrent cervical cancer; 3) Renal impairment approved by the consultant of Kidney Hypertension Division, Department of Internal Medicine Dr. Cipto Mangunkusumo National Central General Hospital. The exclusion criteria were patients lost on follow up.

Sample size used the following formula:

$$
n=\frac{\left[Z_{1-\alpha 2} \sqrt{2 \lambda^{2}+Z_{1-\beta}} \sqrt{\lambda_{1}^{2}+\lambda_{2}^{2}}\right]}{\left[\lambda_{1}-\lambda_{2}\right]^{2}}
$$

Where:

$\lambda^{1}$ is rate of group 1 (nephrostomy),

$\lambda^{2}$ is rate of group 2 (Conservative)

$\lambda=\left(\lambda^{1}+\lambda^{2}\right) / 2$

All patients in the present study were monitored until their death.

Factors considered to affect survival rate and prognosis in ACCRI patients were as follows: (A) clinical characteristic factors: 1) age; 2) clinical stage; 3) type of renal impairment; B) histopathological charac- teristics: 1) histopathological type; 2) cell differentiation; 3) tumor growth pattern; 4) necrosis; 5) lymphvascular reaction; 6) lymphocyte cells surrounding the tumor; C) Characteristic factors of renal pathology: 1) hydronephrosis; 2) cortical thickness/ renal condition; 3) non-visualized kidney; 4) hydroureter; D) Factors of intervention types: 1) conservative; 2) nephrostomy; 3) type of radiation.

Data were analyzed using SPSS and STATA. We used Kaplan Meier test to determine survival rate, while multivariate analysis was used to determine prognostic factors (Table 3 ). Scoring system was used to predict probability of survival after time (Table 4), and probability of death (Tables $4 \mathrm{a}$ and $4 \mathrm{~b}$ ). This study was approved by ethical committee of Dr. Cipto Mangunkusumo National Central General Hospital. We kept the medical records of patients in confidence in accordance with the applicable medical ethics.

\section{RESULTS}

Median survival of six months, and one-year survival rate of ACCRI patients were $39 \%$ and $3.2 \%$, respectively, while median survival was 5.3 months.

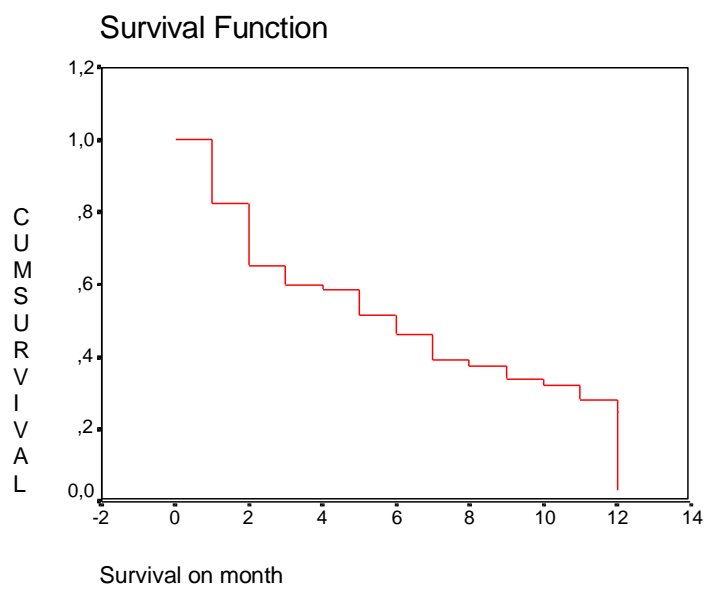

Figure 1. Survival rate of ACCRI patients in month

\section{Multivariate analysis}

Multivariate/cox regression analysis showed that risk factors of survival among ACCRI patients were as shown in table 1. 
Table 1. Variables included in making of hazard ratio model

\begin{tabular}{|c|c|c|c|}
\hline Variable & HR & 95\% CI HR & $P$ value \\
\hline Age $(>=46$ th $)$ & 0.73 & $(0.42 ; 1.25)$ & 0.247 \\
\hline \multicolumn{4}{|l|}{ Histopathological type } \\
\hline adenocarcinoma & 0.47 & $(0.14 ; 1.53)$ & 0.209 \\
\hline Adenosquamous & 3.10 & $(1.07 ; 9.00)$ & 0.037 \\
\hline Small cell & 0.35 & $(0.05 ; 2.58)$ & 0.300 \\
\hline Unknown & 2.04 & $(0.94 ; 4.42)$ & 0.071 \\
\hline \multicolumn{4}{|l|}{ Differentiation } \\
\hline Moderate & 1.15 & $(0.54 ; 2.45)$ & 0.715 \\
\hline Poor & 1.35 & $(0.53 ; 3.42)$ & 0.533 \\
\hline Unknown & 1.95 & $(0.89 ; 4.28)$ & 0.096 \\
\hline $\begin{array}{l}\text { Cortical thickness of } \\
\text { right kidney }(<1 \mathrm{~cm})\end{array}$ & 1.72 & $(0.93 ; 3.20)$ & 0.086 \\
\hline $\begin{array}{l}\text { (Non)/ conservative } \\
\text { nephrostomy }\end{array}$ & 1.78 & $(1.00 ; 3.16)$ & 0.050 \\
\hline \multicolumn{4}{|l|}{ Radiation response } \\
\hline Partial response & 1.64 & $(0.55 ; 4.87)$ & 0.373 \\
\hline Stable & 1.53 & $(0.68 ; 3.46)$ & 0.305 \\
\hline Progressive & 1.15 & $(0.15 ; 9.10)$ & 0.893 \\
\hline Not performed & 2.62 & $(1.25 ; 5.49)$ & 0.011 \\
\hline Blood creatinine & 0.98 & $(0.95 ; 1.01)$ & 0.249 \\
\hline Hemoglobin level & 0.88 & $(0.76 ; 1.02)$ & 0.081 \\
\hline
\end{tabular}

Table 2. Hazard prediction model

\begin{tabular}{lccrrrr}
\hline \multicolumn{1}{c}{ Characteristics } & $\mathrm{HR}$ & $\begin{array}{c}95 \% \mathrm{Cl} \\
\mathrm{HR}\end{array}$ & $\begin{array}{c}\text { Coeffi- } \\
\text { cient }\end{array}$ & $\mathrm{z}$ & $\begin{array}{c}\mathrm{P} \\
\text { value }\end{array}$ & Score \\
\hline $\begin{array}{l}\text { (Non)/ conserva- } \\
\text { tive nephrostomy }\end{array}$ & 2.43 & $(1.10 ; 5.39)$ & 0.8880 & 2.18 & 0.029 & 20 \\
$\begin{array}{l}\text { Histopathological } \\
\text { type: adenocarci- }\end{array}$ & 0.50 & $(0.11 ; 2.32)$ & 0.6958 & 0.89 & 0.376 & -8 \\
$\begin{array}{l}\text { noma } \\
\text { Histopathological }\end{array}$ & & & & & & \\
$\begin{array}{l}\text { type: adenos- } \\
\text { quamous }\end{array}$ & 5.21 & $(1.61 ; 16.80)$ & 1.6500 & 2.76 & 0.006 & 25 \\
$\begin{array}{l}\text { Histopathological } \\
\text { type: small cell }\end{array}$ & 0.20 & $(0.02 ; 1.65)$ & 1.6312 & 1.50 & 0.134 & -14 \\
$\begin{array}{l}\text { Histopathological } \\
\text { type: unknown }\end{array}$ & 1.41 & $(0.52 ; 3.83)$ & 0.3411 & 0.67 & 0.505 & 6 \\
$\begin{array}{l}\text { Moderate differen- } \\
\text { tiation }\end{array}$ & 1.05 & $(0.42 ; 2.67)$ & 0.0534 & 0.11 & 0.910 & 1 \\
$\begin{array}{l}\text { Poor differentiation } \\
\text { Unknown differen- }\end{array}$ & 2.28 & $(0.76 ; 6.88)$ & 0.8245 & 1.46 & 0.143 & 13 \\
$\begin{array}{l}\text { tiation } \\
\text { Cortical thickness of } \\
\text { right kidney }(<1 \mathrm{~cm})\end{array}$ & 2.78 & $(1.39 ; 5.56)$ & 1.0207 & 2.88 & 0.004 & 26 \\
\hline
\end{tabular}

Table 2 showed final model of multivariate analysis and it is evident that factors contributing to survival of ACCRI patients were: nephrostomy (conservative) was not performed, histopathological type of adenosquamous, unknown cell differentiation, cortical thickness of right kidney $<1 \mathrm{~cm}$.

Table 3. Multivariate analysis of prognostic factors among ACCRI patients

\begin{tabular}{|c|c|c|c|c|c|c|}
\hline Characteristic & HR & $95 \%$ CI HR & Coefficient & $\mathrm{z}$ & $P$ values & Scores \\
\hline \multicolumn{7}{|l|}{ 1. Nephrostomy } \\
\hline Yes & 1 & & & & & \\
\hline No & 2.43 & $(1.10 ; 5.39)$ & 0.8880 & 2.18 & 0.029 & 20 \\
\hline \multicolumn{7}{|l|}{ 2. Histophatological subtype } \\
\hline Squamous cell & 1 & & & & & \\
\hline Adenocarcinoma & 0.50 & $(0.11 ; 2.32)$ & -0.6958 & -0.89 & 0.376 & -8 \\
\hline Adenosquamous & 5.21 & $(1.61 ; 16.80)$ & 1.6500 & 2.76 & 0.006 & 25 \\
\hline Small cell & 0.20 & $(0.02 ; 1.65)$ & -1.6312 & -1.50 & 0.134 & -14 \\
\hline unknown & 1.41 & $(0.52 ; 3.83)$ & 0.3411 & 0.67 & 0.505 & 6 \\
\hline \multicolumn{7}{|l|}{ 3. Cell differentiation } \\
\hline Good & 1 & & & & & \\
\hline Moderate & 1.05 & $(0.42 ; 2.67)$ & 0.0534 & 0.11 & 0.910 & 1 \\
\hline Poor & 2.28 & $(0.76 ; 6.88)$ & 0.8245 & 1.46 & 0.143 & 13 \\
\hline Unknown & 4.25 & $(1.49 ; 12.15)$ & 1.4474 & 2.70 & 0.007 & 25 \\
\hline \multicolumn{7}{|c|}{ 4. Cortical thickness of right kidney } \\
\hline$>=1 \mathrm{~cm}$ & 1 & & & & & \\
\hline$<1 \mathrm{~cm}$ & 2.78 & $(1.39 ; 5.56)$ & 1.0207 & 2.88 & 0.004 & 26 \\
\hline
\end{tabular}


The present study showed that the difference in the risk or probability between patients who did not undergo nephrostomy and those who underwent nephrostomy after being controlled by other variables. It was evident from the results of multivariate analysis that in the final model, in addition to nephrostomy as a primary variable, there were several confounders, i.e. histopathological type, cell differentiation, and cortex thickness of the kidney. Based on the final model, the probability for patients who did not undergo nephrostomy to die with the same histopathological type, differentiation cell and renal cortex thickness was 2.43 times as high as those undergoing nephrostomy.

Histopathological type of adenosquamous. Compared with squamous type, the mortality risk in ACCRI pa- tients with adenosquamous cell type was 5.21 times (HR 5.21, 95\%CIHR 1.61-16.80; $p=0.006$ ) with differetiation cell; intervention and the same cortical thickness.

Cortical thickness of the kidney. Patients with cortical thickness of right kidney less than $1 \mathrm{~cm}$ had a mortality risk of 2.78 times (HR 2.78; 95\% CIHR; $1.39-5.56 ; \mathrm{p}=0,004)$ with intervention and histopathology of the Same cell.

In order to predict survival of patients with advanced stage cervical cancer with renal impairment, we used formula of survival prediction and probability of death as follows:

\section{Formula of survival prediction}

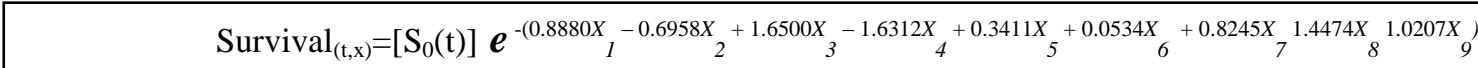
$S_{0}(t)=$ Survival base at the $-t$ time
$X_{5}=$ Histopathological type unknown
$X_{I}=$ Conservative ( non nephrostomy)
$X_{6}=$ Moderate differentiation
$X_{2}=$ Histopathological type adenocarcinoma
$X_{7}=$ Poor differentiation
$X_{3}=$ Histopathological type adenosquamous
$X_{8}=$ Unknown differentiation
$X_{4}=$ Histopathological type small cell
$X_{9}=$ Cortical thickness of right kidney $<1 \mathrm{~cm}$

\section{Survival probability patients on $365^{\text {th }}$ day}

$\begin{aligned} \mathrm{S}_{\mathrm{ACCRI}(\mathrm{t}, \mathrm{x})} & \left.=\left[\mathrm{S}_{0}(\mathrm{t})\right] e^{-(0,8880 X} I_{1}^{-0,6958 X}{ }_{2}+1,6500 X_{3}-1,6312 X_{4}+0,3441 X_{5}+0,0534 X_{6}+0,8245 X_{7}+1,4474 X+1,0207 X\right) \\ & =(0,8139), \mathrm{x}=0,01016182=1,02 \%\end{aligned}$

survival probability of ACCRI patients on the $365^{\text {th }}$ day were $1,02 \%$

\section{Probability of death after $365^{\text {th }}$ day}

$$
\begin{aligned}
\mathrm{P}= & \frac{1}{1+e^{-\left(0,8880 X_{1}-0,6958 X_{2}+1,6500 X_{3}-1,6312 X_{4}+0,3441 X_{5}+0,0534 X_{6}+0,8245 X_{7}+1,4474 X_{8}+1,0207 X_{9}\right)}} \\
\mathrm{p} & =1 / 1012485342 \\
\mathrm{p} & =0,98766862 \\
\mathrm{p} & =98,8 \%
\end{aligned}
$$

Probability of death after 365 days, were 98,8\% 
After calculating the probability of survival, we may also calculate the scoring system in a clinically practical way.

Score value was the multiplication of individual characteristic (IC) with index value (1). Thus, each case would have the score that constituted a total of the above multiplication $(\Sigma(\mathrm{IC} \times \mathrm{I}))$.

Table 4. Enumeration of probability of survival after time (t)

\begin{tabular}{|c|c|c|c|}
\hline Characteristics & $\begin{array}{l}\text { Individual } \\
\text { Values }\end{array}$ & Coefficient & Amount \\
\hline & $\mathrm{NI}$ & $\bar{K}$ & NI $x$ K \\
\hline \multicolumn{4}{|l|}{ Nephrostomy } \\
\hline Yes & 0 & 0 & \\
\hline No & 1 & 0.8880 & 0.880 \\
\hline \multicolumn{4}{|l|}{$\begin{array}{l}\text { Histophatological } \\
\text { subtype }\end{array}$} \\
\hline Squamous cell & 0 & 0 & \\
\hline Adenocarcinoma & 0 & -0.6958 & \\
\hline Adenosquamous & 1 & 1.6500 & 1.6500 \\
\hline Small cell & 0 & -1.6312 & \\
\hline unknown/sensor & 0 & 0.3411 & \\
\hline \multicolumn{4}{|l|}{ Cell differentiation } \\
\hline Good & 0 & 0 & \\
\hline Moderate & 0 & 0.0534 & \\
\hline Poor & 1 & 0.8245 & 0.8245 \\
\hline Unknown/sensor & & 1.4474 & \\
\hline \multicolumn{4}{|l|}{$\begin{array}{l}\text { Cortical thickness of } \\
\text { right kidney }\end{array}$} \\
\hline$>1 \mathrm{~cm}$ & 0 & 0 & \\
\hline$<1 \mathrm{~cm}$ & 1 & 1.0207 & 1.0207 \\
\hline Total (NI x K) & & & 4.3832 \\
\hline
\end{tabular}

Table 4a. Enumeration of probability of survival after time ( $\mathrm{t}$ )

\begin{tabular}{|c|c|c|c|}
\hline Characteristics & $\begin{array}{c}\text { Individual } \\
\text { Characteristic }\end{array}$ & Index & Scores \\
\hline & $\mathrm{KI}$ & $\mathrm{I}$ & $\mathrm{KI} \times \mathrm{I}$ \\
\hline \multicolumn{4}{|l|}{ Nephrostomy } \\
\hline Yes & 0 & 0 & \\
\hline No & 1 & 20 & 20 \\
\hline \multicolumn{4}{|l|}{$\begin{array}{l}\text { Histophatological } \\
\text { subtype }\end{array}$} \\
\hline squamous cell & 0 & 0 & \\
\hline Adenocarcinoma & 0 & -8 & \\
\hline Adenosquamous & 1 & 25 & 25 \\
\hline small cell & 0 & -14 & \\
\hline Unknown/sensor & 0 & 6 & \\
\hline \multicolumn{4}{|l|}{ Cell differentiation } \\
\hline Good & 0 & 0 & \\
\hline Moderate & 0 & 1 & \\
\hline poor & 1 & 13 & 13 \\
\hline Unknown/sensor & & 25 & \\
\hline \multicolumn{4}{|l|}{$\begin{array}{l}\text { Cortical thickness of } \\
\text { right kidney }\end{array}$} \\
\hline$>1 \mathrm{~cm}$ & 0 & 0 & \\
\hline$<1 \mathrm{~cm}$ & 1 & 26 & 26 \\
\hline Total Scores & & & 84 \\
\hline
\end{tabular}

Table $4 \mathrm{~b}$. Death prediction conversion of cervical cancer

\begin{tabular}{cc}
\hline Total Scores & Death Prediction \\
\hline$\leq-7$ & $67-70 \%$ \\
-1 s.d. 11 & $71-80 \%$ \\
13 s.d. 31 & $81-90 \%$ \\
\hline$>39$ & $>90 \%$ \\
\hline
\end{tabular}

ACCRI patient did not undergo Nephrostomy (conservative) histopathological type : adenosquamous, poor differntiation; cortical thicknes $<1 \mathrm{~cm}$ Showed table ( 4 and $4 a$ ) were total score 84 .

Since the total score more than 39 , death prediction $>90 \%$ ( tabel 4b).

\section{DISCUSSION}

Probability of survival in ACCRI patients with renal dysfunction in the $6^{\text {th }}$ month was $39 \%$, while the cummulative probability in the $12^{\text {th }}$ month was $3.2 \%$, and median survival was 5.1 months. As shown in the annual FIGO report, mean survival of cervical cancer patients was $55 \%$. At the advanced stages, i.e. stage III and IV, the five-year survival was still high, i.e. $31.0 \%$ and $7.8 \%$ respectively.

In the present study, with the presence of renal dysfunction the survival rate that the one year survival drops to $3.2 \%$. The study conducted by Gaspari M et.al, showed that survival of ACCRI patients was not influenced by age and renal impairment. ${ }^{9}$

Harrington KJ et.al: found that the median survival in all patients with ureteral obstructions leading to malignancies was \pm 133 days (with a range of 7-7-12). Seventeen patients (40\%) survived up to 6 months and 5 patients (12\%) up to 1 year. $^{8}$

Median survival after nephrostomy was 526 days, with a range of 1-712 days. The study of prostate cancer showed that overall survival rate was $57 \%$ for 1 year and $29 \%$ for 2 years (median survival was 21 months). Another study of prostate cancer found an overall survival rate of $60 \%$ for the 1 year and $32 \%$ for 2 years. ${ }^{9}$

With respect to prognostic factors in advanced stage cervical cancer with renal dysfunction, Culkin DJ et. al found that the type of histopathology was the main determining factor for survival in prostate, rectal, and cervical cancer. However, this was not the case 
with bladder cancer in which there was no independent factor for significant prognosis.

On the other hand, Roesma J.et.al. found cortical thickness of $<1 \mathrm{~cm}$, showed that the kidney has suffered an irreversible process. However, nephrostomy may be considered for cortical thickness $>1 \mathrm{~cm} .{ }^{10}$

The aforementioned studies that supported the results of the present study showed that the prognostic factors in ACCRI patients were: (1) Type of histopathology (Adenosquamous cell); (2) Cell differentiation; (3) cortical thickness $(<1 \mathrm{~cm})$, and (4) Nephrostomy.

By taking into consideration the above-mentioned prognostic factors, we might be able to predict patients' survivability using survival prediction scoring.

\section{CONCLUSIONS}

1. Median survival among ACCRI patients was 5,31 months, while six months and 1 year survival among ACCRI patients were $39 \%$ and $3.2 \%$, respectively. The overall mean of one-year survival of ACCRI patients was 8.2 months, with survival in the sixth month at $39 \%$, and survival in one year at $3.2 \%$. Median survival was 5.31 months.

2. As shown in multivariate analysis, prognostic factors that affected survival among ACCRI patients included: (a) Histopathological subtype, (adenosquamous cells and cell differentiation), (b) cortical thickness $<1 \mathrm{~cm}$ (c) nephrostomy.

3. By using scoring system, we may be able to predict the probability of death in advanced stage cervical cancer patients with renal impairment.

\section{Acknowledgments}

The authors would like to express their gratitude and appreciation to the trainees in gynecological oncology and the staff of Oncology Division, Department of Obstetrics and Gynecology, Department of Urology, Department of Radiotherapy, Department of Internal Medicine, Faculty of Medicine, University of Indonesia, for their cooperation during this study.

\section{REFERENCES}

1. Saroyo YB, Sjamsudin S, Hardjolukito, Bachtiar A. Densitas mikrovaskular tumor as factor of predictor radiotherapy response [at] cell cancer of skuamosa serviks. Maj Obstet Ginekol Indones 2000;24:109-16

2. Hopkins MP, Morley GW. Prognostic factors in advanced stage squamous cell cancer of the cervix. Cancer. 1993 Oct 15;72(8):2389-93.

3. Nuranna L, Kampono N, Aziz MF, Sjamsuddin S, Andrijono, Taher A, et al. Management of advanced cervical cancer with renal failure (abstract), Bali, AOFOG, 1995.

4. Aziz MF, Kampono N, Sjamsudin S, Andrijono, Nuranna L, Purbadi S, et.al. Sub Units of Oncology Gynecology Guidance of service of education of research. 1st ed. Jakarta: Department Obstetric Gynecology of FKUI; 1998:37

5. Ahmed I, Rizvi IH, Aslam A, Ahmed MN, Hussain YA. Effectiveness of percutaneous nephrostomy in reversing obstruction renal failure. J Pak Med Assoc. 1995 Jan; 45(1):16-8.

6. Demetriu D, Sebeikat D. Percutaneous nephrostomy in malignant ureteral obstruction. Deutsch Med Wochensechr. 1996;121(49):1526-30.

7. Sukandar E. clinic nephrology, edition to II, publisher of ITB Bandung; 1997 matter. 97-109, 284-388. Culkin DJ, Wheeler JS Jr, Marsans RE, Nam SI, Canning JR. Percutaneous nephrostomy for palliation of metatastic ureteral obstruction. Urology. 1987;30(3):229-31

8. Harrington KJ, Pandha HS, Kelly SA, Lambert HE, Jackson JE, Waxman J. Palliation of obstructive nephropathy due to malignancy. Br J Urol. 1995; 76(1):101-7.

9. Gasparini M, Carroll P, Stoller M. Palliative Percutaneus and endoscopic urinary diversion for malignant ureteral obstruction. Urology. 1991; 38(5):408-12.

10. Jose Roesma, Endang Susalit, Pemeriksaan Penunjang pada Penyakit Saluran Kemih, dalam Ilmu Penyakit Dalam jilid II, Balai Penerbit FKUI, Jakarta, 1990. 
